\title{
Towards a historical context of chemical weapons
}

Benjamin Ruiz Loyola

Faculty of Chemistry, National Autonomous University of Mexico, Mexico.

Corresponding Author: Benjamin Ruiz Loyola, Faculty of Chemistry, National Autonomous University of Mexico, Mexico.

Received date: December 16, 2020; Accepted date: January 25, 2021; Published date: February 17,2021

Citation: Benjamin R. Loyola (2021) Towards a historical context of chemical weapons J. Pharmaceutics and Pharmacology Research. 4(2); DOI: 10.31579/2693-7247/026

Copyright: (c) 2021, Benjamin Ruiz Loyola, This is an open access article distributed under the Creative Commons Attribution License, which permits unrestricted use, distribution, and reproduction in any medium, provided the original work is properly cited.

Abstract
Chemical weapons remain a worrisome aspect worldwide. Knowing its history is essential to avoid
repeating it and to be able to leave our planet free of this scourge. The threat of its resurgence is
something tangible and real against which we must all fight, each one from his own trench.
Key words: chemical weapons, history, threat, resurgence, chemical weapons convention

\section{Introduction}

Man has always had the tendency to imitate nature. Perhaps that is why the invention of the first chemical weapons occurred, taking into account certain animals that defend themselves using chemical substances. Take, for example, the skunk, which emits a stinking chemical when threatened, which gives him time that, for him, is more than enough to run away and take refuge. There is also a species of frog that spews poisoned saliva that immediately paralyzes the living being that is touched by it, allowing the batrachius to flee or feed, as the case may be. Poisonous snakes are another example, but there must be physical contact between the snake and its victim. As a last reference to chemical defense or attack systems with which nature provides certain animals, it is known that a certain beetle exists that has a kind of reserve warehouse in the back of its body, in which it keeps two separate chemicals; one is hydrogen peroxide and the other is hydroquinone. At the minimum contact with an enemy, or at the slightest sense of danger, without the need for such physical contact, both substances pass into a chamber that is connected to a kind of tube that is located on the back of their shell. In that chamber the walls secrete an enzyme (of the albuminoid type) called peroxidase that mixes with the aforementioned substances, carrying out a chemical reaction in fractions of a second; hydroquinone is converted to benzoquinone (a highly oxidizing compound that causes severe irritation on the surfaces it touches, even at room temperature) and the temperature rises to more than $100^{\circ} \mathrm{C}$. The tube-shaped outlet leads the liquids to the outside, spraying the attacker, all of which is accompanied by a loud hissing sound reminiscent of the one emitting a kettle of boiling water. This natural system becomes the living antecedent of binary chemical weapons, embodied in the so-called Big Eye Project of the United States.

The oldest verified antecedent of the use of chemical weapons dates back to $431-404 \mathrm{BC}$, in the Peloponnesian war between Sparta and Athens, during which sulfur dioxide and other fumes obtained by direct combustion were used, for the immobilization of troops inside a fort, piercing one of the walls of the fort and directing the smoke directly towards it. This system has been widely used to evacuate closed places, such as caves, burning green branches at the entrance to them.

Before this fact, there are references that the Chinese used arsenic fumes a thousand years before Christ; It is also mentioned that Solon of Athens placed toxic roots (white hellebore) to poison the water of the Pleistrus River, during the siege of the city of Cirrha, in the year 590 BC. Around 200 BC, the Carthaginians used mandrake root in the he came to sedate his enemies. The so-called "Greek fire" by the Byzantine Empire, around the 5th century, was an incendiary weapon based on chemicals. In 1591 the Germans made pestilential bombs using smashed animal hooves and horns, mixing them with Asafetida (a resinous gum that, as its name indicates, is fetid and, colloquially, in different countries and languages it is known as devil's shit) and setting them on fire.

During the Crimean War, several proposals were made to use chemical weapons, particularly for the Sevastopol site; Louis XIV (1643-1715) is said to have been offered such a weapon by an Italian chemist, and the monarch awarded him with a lifetime pension "on the condition that he never disclose his invention." In 1854, Lyon Playfair (British chemist) proposed the use of artillery pieces filled with cacodyl cyanide, to be launched against enemy ships, but his proposal was rejected. Playfair's answer spelled out a concept that seems to have been used as justification for developing chemical warfare in the next century:

"There was no point in that objection. It is considered a legitimate form of war to fill containers with molten metal to disperse it over enemy troops resulting in appalling deaths. It is incomprehensible why a poisonous vapor that would kill men without suffering is considered illegitimate. War is destruction and the more destructive it is, with less suffering, the more quickly this barbarous method of protecting national rights will end. There is no doubt that the time will come when chemistry will be used to reduce the suffering of combatants, as well as those of criminals sentenced to death." 
It seems that these words inspired Fritz Haber, a famous German chemist, to convince his government of the use of chemical weapons during the First World War. And to think that years later he would receive the Nobel Prize in Chemistry!

\section{WWI}

The first German attempt to use chemical weapons consisted of $105 \mathrm{~mm}$. projectiles, filled with dianisidine chlorosulfate, a lung irritant; A projectile charge would be added to the projectiles so that they did not have as their sole purpose the dissemination of the irritant and, thus, to respect the treaties of 1899 signed at The Hague. On October 27, 1914, they shot 3,000 of these projectiles against the British forces, without visible effect; the explosive portion of the projectile ended up destroying the chemical compound. Fritz Haber managed the concept of creating toxic clouds from gas cylinders, an idea developed in late 1914. This represented a possible saving in the development of artillery pieces to transport any toxic products. On March 10, 1915, in an action supervised by Haber himself, the Pioneer Regiment 35 began laying 1,600 large cylinders and 4,130 small cylinders, filled with chlorine, along the trenches of Ypres, in Belgium. German troops received oxygen equipment similar to those used in mines, and the infantry on the same battlefront had small pads soaked in sodium thiosulfate as an antidote. After placement, it was simply a matter of waiting for the wind to blow in the direction the Germans wanted (westward). On April 22, 1915, the Germans opened the valves and attacked the Allied forces with 168 tons of chlorine gas, thereby causing 15,000 cases of poisoning, including 5,000 deaths. Chlorine was also used against the Soviet army on the Polish front. With these deplorable actions chemical warfare started in the modern era. It is estimated that between 1915 and 1918, a total of 125,000 tons of toxic chemical compounds were used, which caused 1,300,000 casualties, including more than 90,000 deaths. The most widely used agents were chlorine, phosgene, tear gas, and mustard gas. By the end of 1918 , an estimated $50 \%$ of all projectiles launched by all contenders were filled with chemicals.

This large-scale use of gases and their devastating effects turned out to be a traumatic experience, reinforcing popular demands for the prohibition of such methods of war. From the point of view of the militia, the chemical compounds proved their high strategic and operational value in the event of a major war, but they also demonstrated all the horror that can be achieved in a war. In 1925, after arduous diplomatic efforts, an international conference was held in Geneva, from which emerged the Protocol for the Prohibition of the Use of Asphyxiating, Poisonous or Other Gases, and of Bacteriological Methods of Military Operations. After some discussions and modifications, the Geneva Protocol (as it is more commonly known) was signed on June 17, 1925. This was the first global attempt to ban this kind of weaponry.

\section{Between wars}

In the period between wars, there were various aggressive acts that involved the use of chemical compounds as a war method; we will mention some of them:

1935-1936. Italian aviation uses mustard gas and phosgene during the invasion of Ethiopia. The use of these gases is supposed to shorten the war for Italy. This action marks the first gap opened in the Geneva Protocol. The sanctions imposed by the League of Nations against Italy for this violation did not have an appreciable impact.

1937-1939. Japan uses yperita (a vesicant gas) in its war against China, which will last until 1945. This action had much less international diffusion than that carried out by Italy, since the European events captured almost all the world attention; however, it is a topical issue because hundreds of artillery pieces filled with chemical agents have been discovered in Chinese territory and there is controversy about the responsibility to move and destroy these weapons, which due to their age and mold, they have already wreaked havoc on the civilian population of various populations.

During this period, very intense research was carried out on the development of new and more powerful chemical weapons. The Germans classified their chemical weapons into four main subdivisions:

"White Cross": Substances such as bromine, chloroacetophenone, or bromoacetic esters, which are irritating but not lethal compounds (known as tear or irritants).

"Green Cross": Suffocating compounds such as chlorine or phosgene, which affect the lungs and cause death from pulmonary edema.

"Blue Cross": Compounds that block the respiratory system, such as hydrogen cyanide, which cause death by suffocation.

"Yellow Cross": The compounds with the greatest dangerous effects, such as mustard gas and Lewisite.

In addition, in the most rigorous secret and under absolute security, there were nerve gases, the first of which was the so-called Tabun. On December 1936, Dr. Gerhard Schrader is said to have first synthesized Tabun (later named by the Americans as GA, an acronym of German agent A), in the city of Leverkusen, working for the IG Farbenindustrie laboratories. His intention was, as he had been doing since 1934, to develop a new type of insecticide. The potency of this new compound was such that it left him more than pleasantly surprised; with a minimal amount, he eliminated all the lice he was working on.

In January 1937, Schrader and his laboratory assistant were accidentally exposed to some Tabun fumes and began to experience miosis (pupil contraction) and respiratory difficulties. They were indeed very lucky to come out of that accident alive.

In 1935 the Nazis issued a decree requiring that any invention or discovery that might have military significance be reported to the Ministry of War, so that a sample of Tabun was sent to the chemical weapons section of the army weapons office, in May 1937. Schrader had to appear in Berlin for a demonstration, while the patent was kept secret. Colonel Rüdiger, head of the chemical weapons section, ordered the construction of new laboratories for further research on Tabun and other organic phosphoric compounds (containing phosphorous), and Schrader was relocated.

The production of Tabun on a pilot plant scale began in 1939 and in January 1940 the construction of the industrial plant began, with the capacity to synthesize absolutely all the intermediaries; in the basement there was all the necessary facilities for filling ammunition with the Tabun, so that there was no movement of the isolated chemical product. The plant was completed in June 1942, with quartz and silver pipes (to avoid corrosion), but even before officially started working, 300 accidents occurred; at least 10 workers died in two and a half years of production. Research work intensified, and in 1938 another nerve agent was discovered, named Sarin (named by the US Army as GB) in honor of his four discoverers: Schrader, Ambros, Rüdiger, and van der Linde. In the spring of 1944, Richard Kuhn discovered Soman, working for the German army; the writings describing their work were buried in a mine shooting 10 miles east of Berlin, from which they were rescued by the Soviet army. 


\section{WWII}

During the main warfare actions of World War II, the use of chemical weapons was not reported; it is believed that the main causes for this were:

a) the dissuasion between both sides participating in said activities, because the use of such weapons would be followed by a counterattack using the same type of weapons;

b) the reluctance of governments towards the use of such weapons;

c) the pressure exerted by public opinion; d) the restrictive influence of the Geneva Protocol; and

e) the lack of preparation of the contending armed forces to use this type of weapon. An important issue is that Adolf Hitler was personally one of the victims who survived a chemical attack during the first great war, and opposed its use.

Although none of the parties to the conflict used chemical weapons in World War II, there were problems with these types of agents. In September 1943, the port of Bari was taken over by the British Army and thereafter used by the Allies to transport provisions, mainly ammunition, to support the advance of troops that would eventually expel the Germans from Italian territory; Italy had already given up and changed sides. The port had a strategic location, despite which its defenses were extremely deficient.

On December 2 there were reconnaissance flights by German aviation, realizing that there were around 30 supply ships in the port, of Polish, Norwegian, Dutch, British and American nationalities. At around seven in the afternoon the German bombers began their attack on the port; merchant ships were sunk or destroyed, of which 3 could be recovered. 12 more ships were slightly damaged. Let's focus on one of the ships, the SS John Harvey, which was carrying a secret cargo of 2,000 M47A1 bombs containing on average $30 \mathrm{~kg}$ of mustard gas each. The impacts of the bombardment caused the mustard to be released, affecting hundreds of sailors who had fallen into the water, as well as the civilian population of the town. On the first day, 628 injured people appeared, including medical personnel who were not prepared to work with this chemical. By the end of the month, 83 of the initial 628 injured people had died. So without using chemical weapons during the Second World War, there were victims due to the effects of those weapons ${ }^{1}$.

\section{Postwar period}

Research done after the Second Great War led to the discovery of a compound even more toxic than previous ones, the so-called VX (in the United States), in parallel to the development in the Soviet Union of the so-called R-VX (from English Russian-VX). In addition, in Russia, investigations have continued, according to statements by several expatriate scientists, in a secret project initially called Foliant, which has led to the production of agents called Novichok, similar in formula to the original VX, but much more powerful (for example, the novichok-5 would be 5 to times more lethal than the VX). After the Second World War, there have also been cases of the use of chemical weapons; some of them are:

Egypt, intervening in the Yemen civil war, between 1963 and 1967, used phosgene and mustard gas.
The United States, in the Vietnam War, used large amounts of 2,4-D, 2,4,5-T, picloram, and cacodylate; according to reports published in the United States itself, $10 \%$ of forests, $30 \%$ of mangroves and $3 \%$ of arable land in Vietnam were affected as a result of these actions. Additionally, the use of dioxin-contaminated defoliants caused immediate deaths, cancer proliferation and birth defects both among the militia and among the civilian population. The so-called orange agent matter has not yet been fully resolved in the US courts. This also explains the fact that the United States had signed the Geneva Protocol, but at the time of the Vietnamese conflict and during the course of it, it would not have ratified it. In fact, the Protocol was outside the North American Congress from 1947 to 1970, being approved in 1974; the war ended with the peace instrument signed in Paris in 1973.

At the end of the Second World War and for more than 25 years, a part of the fighters's arsenals was buried in the ocean, where it is supposed to remain until the moment, if they have not disintegrated and dissolved or reacted with sea water (even though many of them were introduced inserted in concrete, there is nothing certain as to whether the blocks remain intact). Another part of the stockpiles has been kept in storage, awaiting the opportunity to be used or destroyed. Several accidents have been recorded during the storage period or when encapsulated in cement to send them to the bottom of the sea, which account for the enormous risks involved. We will mention a couple of them only.

On July 8, 1969, 23 soldiers and one civilian were reported to have been affected by sarin in Okinawa. None of those affected died and the accident occurred when the soldiers were preparing some bombs full of the chemical agent, to paint them. The controversy about the storage of chemical weapons and the enormous risk that this implies immediately broke out, in addition to exposing the Americans who, until then, had kept the existence of such weapons secret in Okinawa.

During the 1980s, Iraq used chemical weapons, mainly mustard gas, hemogases and nerve gases, against Iran and against the Kurdish rebels. Very particularly, the complaints multiplied during 1987. Some 2013 reports affirm that the CIA provided classified information to Saddam Hussein about the best targets to attack Iran with chemical agents, especially in 1988. In that particular year, satellite images made it possible to determine that the Iranian army was about to take advantage of certain weaknesses in Iraq that would give them important strategic advantages, so they alerted Hussein and encouraged him to use chemical weapons.

The results of these bloodless actions allowed Iran to be the most advanced country in curative medicine and in the investigation of the effects of chemical weapons; over the years they have found, for example, that mustard gas produces, in the long term (in addition to blistering effects), corneal disintegration, tooth decay and dementia.

In 1993, finally, the Chemical Weapons Convention was opened to signature, and entered in force in 1997, which led to a great amount of work in the fields of disarmament and destruction of chemical weapons ${ }^{2}$.

Additionally, unproven charges have been leveled against various countries in the post-World War II era; thus, it is alleged that the USSR used them to fight in Afghanistan, and that it provided them to North Vietnam to use them against Laos and Campuchea. In the last decade of the century, Yugoslavia was accused of using them against Bosnia, and Russia received accusations of using some ones of a hitherto unknown type against Chechnya. If this is true, it would be found that the Russians 
continued to research and develop chemical weapons, even after signing and ratifying the Convention. And so we ended the 20th century and gave way to the 21 st.

\section{1st CENTURY}

The States Parties to the Convention for the Prohibition of Chemical Weapons (CAQ), since 1997 have proceeded to fulfill the obligations that this agreement imposes. However, there are States that took time to join and, therefore, it was not applicable to them. When the Allied armies invaded Iraq, in 2003, that country was not part of the CWC and a few years later, when the regime changed, it did so. Syria was also not a party to the Convention and it was suspected since the 1980s that it had this type of weaponry. In July 2012, the Syrian foreign ministry, through its spokesman Jihad Makdissi, accepted to have stored chemical weapons and declared that they would never be used against the Syrian people, they would only be used against external aggressions. In December of that same year, the first report of the use of these compounds was given by the Assad government, in the Homs region. On March 19, 2013, there were attacks in both Aleppo and Damascus, both parties involved, the government and the pro-independence rebels, being accused of their use. The Assad government requested the following day that the UN investigate the Aleppo incident; The UN organized, in conjunction with the OPCW (Organization for the Prohibition of the Chemical Weapons), an investigative commission, while the events continued and the blame continued to be distributed. On September 12, the Assad government signed and ratified its accession to the CWC and began handing over its arsenal and allowing free access to OPCW inspectors. The commitments were slowly being honored and in the meantime there were reports of the use of chlorine in different places, for example on April 11, 2014, in Kafr Zita, a place controlled by the rebels. By the end of 2014 Syria had already turned over to the OPCW all of its stored chemical weapons, however the use of chlorine remained a constant issue.

Despite the fact that Syria officially no longer had chemical weapons, in May 2015 sarin and VX were detected in undeclared military sites by the government. In August 2016, a report by the UN-OPCW joint commission found the Assad regime guilty of attacks with chemical weapons in Taimenes (April 2014) and in Sarmin (March 2015), in clear violation of the CAQ; extremely disturbingly, they also found that an attack with sulfur mustard carried out in Marea in August 2015 was attributable to the Islamic army ISIS. And the matter goes on.

On April 4, 2017, there was a brutal attack in Idlib province with sarin. There were allegations against the Assad regime (and retaliation by Donald Trump with Tomahawk missiles) and against the rebels (by the government, with the support of Russia). The OPCW stated that there was incontrovertible evidence of the use of sarin or a similar substance in Idlib. Although the Syrian issue has not been resolved, despite being a State Party to the CWC, things get complicated when an actor who is not a State Party enters the scene, indeed, it is not even a State under the international law. We refer to the so-called Islamic State ISIS, which, because it does not have a territory, moves between countries and manifests itself mainly in Iraq, Syria and a small area in southern Turkey. More than 50 attacks with sarin, mustard and chlorine are attributed to this group since 2014 .

And the Salisbury events in Britain in March 2018 resulted in the discovery of a new class of weapons that were suspected but not confirmed: the Novichok calls, which led to intense chemical investigation. And a great diplomatic debate, which had the conclusion of the modification to list of the CWC, in 2019, but which, due to legaldiplomatic procedures, is not yet reflected, at the time of writing this contribution, in the mentioned list itself.

\section{Epilogue}

Scientists have the power to give humanity the tools to have a future where technological advances are beneficial concepts that help build. It is true that it is much easier to destroy than to build, and that the human tendency is sometimes reflected in its aggressive instincts, but the latter can be fought. We must believe and trust that humanity has the ability to fight hate if it sets its mind to it. Once we put aside our differences, understand that weapons and violence lead to nothing, and think about the long-term future with its consequences, we can together build a superior society where peace is sustained by values and ethics. Scientists must realize through reading and education, the relevance of being the pioneers in this field and the transcendental importance of ensuring that the contributions we make are responsible and beneficial.

\section{References}

1. Handbook on the medical aspects of NBC defensive operations, FM 8-9, Part III-Chemical, Department of the Army, Washington, D. C., 1996.

2. Paxman, J., Harris, R. (1982) A higher form of killing: The secret story of chemical and biological warfare Hill and Wang New York.

3. J. Michael Waller The chemical weapons coverup The Wall Street Journal. Feb. 13, 1997.

4. Chemical Weapons News Alert Top Russian scientists urges support The White House April 21, 1997.

5. Benjamín Ruiz Loyola. (2019) Salisbury, Novichok and the OPCW. LOJ Phar \& Cli Res 1(4). 